\title{
Effect of dry period management on mammary gland function and its endocrine regulation in dairy cows
}

\author{
P. Bernier-Dodier, ${ }^{\star}$ C. L. Girard, $†$ B. G. Talbot, ${ }^{\star}$ and P. Lacasse $\dagger^{1}$ \\ *Département de Biologie, Faculté des Sciences, Université de Sherbrooke, Sherbrooke, QC, Canada J1K 2R1 \\ †Dairy and Swine Research and Development Centre, Agriculture and Agri-Food Canada, PO Box 90 STN Lennoxville, Sherbrooke, QC, \\ Canada J1M 1 Z3
}

\section{ABSTRACT}

The objective of this study was to evaluate the effect of shortening the dry period on the mammary gland and the hormonal regulation of its functions. Holstein cows $(\mathrm{n}=18)$ were assigned to a short dry period (SDP; $35 \mathrm{~d} ; \mathrm{n}=9$ ) or a conventional dry period (CDP; $65 \mathrm{~d} ; \mathrm{n}=9$ ). All cows were fed the same diets, with the exception that, during the dry period, the SDP cows received only the pre-calving diet for $35 \mathrm{~d}$, whereas the CDP cows were fed a high-fiber diet from 65 to $28 \mathrm{~d}$ before calving and then received the same pre-calving diet as the SDP cows. Mammary gland functional capacity was evaluated at 70 days in milk, and mammary biopsies were taken in early and midlactation. Dry period length averaged $64.3 \pm 1.1$ and $31.9 \pm 1.0 \mathrm{~d}$ for the CDP and SDP cows, respectively. The SDP cows had a lower milk yield and a lower energy-corrected milk yield compared with the CDP cows. The SDP cows also had a lower dry matter intake from wk 5 to 20 of lactation and tended to have lower plasma concentrations of $\beta$-hydroxybutyrate from wk 1 to 4 . Prepartum serum progesterone and estradiol concentrations were unaffected by the dry period management. Serum growth hormone concentrations and milking-induced prolactin release were similar in both groups. However, during the period when the CDP cows were dry but the SDP cows were still being milked (wk -9 to -6 ), serum prolactin concentrations were higher in the SDP cows than in the CDP cows. The SDP cows had a lower milk BSA content than the CDP cows after the dry period and similar milk lactose concentrations, suggesting that their mammary tight junctions were closed following parturition and, therefore, that the later stage of their lactogenesis was not impaired by SDP management. In early and midlactation, mammary cell apoptosis and proliferation rates as well as mammary expression of genes involved in the function of this tissue were unaf-

Received December 20, 2010.

Accepted May 30, 2011.

${ }^{1}$ Corresponding author: lacassep@agr.gc.ca fected by the dry period management strategy. For cows in their second lactation, mammary gland functional capacity at $70 \mathrm{~d}$ in milk tended to be lower in the SDP cows. In conclusion, even though SDP management decreased milk production during the subsequent lactation, it did not affect mammary cell activity. Although direct evidence is still lacking, decreased mammary cell growth during the dry period is likely responsible for this negative effect. The higher prolactin concentrations in lactating cows during late gestation could be involved in this effect. More research is needed to test these hypotheses.

Key words: dairy cow, dry period management, milk production, prolactin

\section{INTRODUCTION}

In past decades, a dry period of $60 \mathrm{~d}$ has been routinely recommended. However, interest is now growing in re-evaluating the length of the dry period, because a short dry period (SDP) has several advantages over a conventional dry period (CDP) of 55 to $70 \mathrm{~d}$. First, an SDP extends the lactation before drying-off, thus giving additional milk. Moreover, because a high milk yield at drying-off increases susceptibility to mastitis (Newman et al., 2010), an SDP could be beneficial for mammary gland health by allowing the cow to reach a lower milk yield before the cessation of milking. In addition, an SDP allows a decrease in the number of dietary changes during the dry period, which could facilitate ruminal adaptation during the transition period and decrease the incidence of postpartum disorders (Bachman and Schairer, 2003). However, decreasing the dry period length to less than $40 \mathrm{~d}$ has frequently been reported to decrease milk yield during the subsequent lactation (Sørensen and Enevoldsen, 1991; Gulay et al., 2005; Rastani et al., 2005; Pezeshki et al., 2007; Church et al., 2008; Watters et al., 2008), thus offsetting the potential benefits of an SDP.

Omission of the dry period decreases milk production following parturition (Annen et al., 2007; Fitzgerald et al., 2007; Madsen et al., 2008). Although this 
decrease is generally greater than the one subsequent to an SDP, the cause is likely the same. Three hypotheses were proposed to explain the negative effects of continuous milking (CM; Annen et al., 2004a). First, as milk production requires great amounts of energy, SDP or omission of the dry period could compromise the replenishment of body reserves before parturition. However, Rastani et al. (2005) have reported that cows on CM or SDP lose less weight following parturition than CDP cows despite lower milk production, ruling out the body reserve hypothesis. A second hypothesis is that the endocrine milieu associated with milk production during late gestation interferes with the preparation of the mammary gland for the next lactation. Half-udder studies showed a negative effect of CM (Annen et al., 2007; Fitzgerald et al., 2007) and SDP (Gulay et al., 2005) on the cows' postpartum milk production. Because, in those studies, all quarters were exposed to the same endocrine environment, this suggests that endocrine regulation is not implicated in the negative effect of CM or SDP. However, in half-udder studies, responsiveness of the gland to systemic factors might be locally affected; therefore, the endocrine hypothesis cannot be ruled out. Finally, regeneration of the mammary tissue could be impaired by CM or SDP. It was shown that, in the absence of a dry period, late gestation mammary cell turnover was limited when compared with glands on a CDP (Capuco et al., 1997), which is likely critical for subsequent milk production.

The exact cause of the decreased milk production subsequent to an SDP is still uncertain, and this lack of knowledge limits our ability to develop tools that could alleviate or overcome this problem. Therefore, the objective of this study was to evaluate the effects of SDP management on mammary gland physiology.

\section{MATERIALS AND METHODS}

\section{Animals and Experimental Procedures}

Holstein cows $(\mathrm{n}=18)$ from the herd at Agriculture and Agri-Food Canada's Dairy and Swine Research and Development Centre (Sherbrooke, QC, Canada) were cared for in accordance with the guidelines of the Canadian Council on Animal Care (1993). The cows included in this study showed no clinical signs of mastitis and were assigned to either a conventional, 65-d dry period $(\mathrm{n}=9)$ or a short, 35-d dry period $(\mathrm{n}=$ 9) according to their 305-d milk production (predicted at $239 \pm 2$ DIM) and calving date. The parity of the cows was not equivalent in both groups, because some multiparous cows had to be removed from the experi- ment (illness: 2; dry period length: 1). Consequently, 7 primiparous and 2 multiparous cows were in the SDP group and 4 primiparous and 5 multiparous cows were in the CDP group. The cows were kept in a tiestall barn, and lactating cows were milked twice daily throughout the experiment, at 0700 and $1900 \mathrm{~h}$. The cows assigned to SDP management were fed a latelactation diet (Table 1) until $3 \mathrm{~d}$ before drying-off; during those $3 \mathrm{~d}$, they were fed a limited amount of late-lactation diet ( $40 \%$ of their needs) complemented with dry hay. The cows in the CDP management group were fed the same late-lactation diet as the SDP cows until the last week before drying-off; the CDP cows were then fed only dry hay for $1 \mathrm{wk}$. During the dry period, the SDP cows were fed the pre-calving diet, whereas the CDP cows were fed a high-fiber diet (faroff diet) until $28 \mathrm{~d}$ before calving and then received the same pre-calving diet as the SDP cows (Table 1). Both groups were fed the same early-lactation diet following parturition (Table 1). Refusals were weighed daily at $1000 \mathrm{~h}$, and feed was served once per day at $1030 \mathrm{~h}$. In lactating cows, milk yield was measured at each milking from wk 14 prepartum to wk 20 postpartum.

Milk samples were collected weekly during lactating periods from wk 12 prepartum to wk 20 postpartum. Aliquots of the milk samples were defatted by centrifugation $\left(1,000 \times g, 15 \mathrm{~min}, 4^{\circ} \mathrm{C}\right)$ and then frozen, and other aliquots were treated with a preservative and sent to a commercial laboratory for analysis (see Milk Composition section). A Vacutainer system (Becton, Dickinson and Co., Rutherford, NJ) was used to collect blood samples from the tail vein weekly from wk 12 prepartum to wk 20 postpartum and twice per week during wk 1 to 4 after calving. Following blood collection, tubes with heparin were kept on ice until centrifugation $\left(5,000 \times g, 10 \mathrm{~min}, 4^{\circ} \mathrm{C}\right)$, and tubes without additive for serum collection were left at room temperature for approximately $2 \mathrm{~h}$ before centrifugation $(5,000$ $\left.\times g, 10 \mathrm{~min}, 4^{\circ} \mathrm{C}\right)$. Plasma and serum samples were then kept at $-20^{\circ} \mathrm{C}$ until analysis.

In early lactation $(19 \pm 1 \mathrm{DIM})$ and midlactation (152 \pm 2 DIM), a catheter was inserted into the jugular vein of each cow. Following the insertion procedure, the catheters were filled with heparin $(500 \mathrm{IU} / \mathrm{mL}, 2 \mathrm{~mL})$. On the following day, serum samples were collected at the morning milking $(-20,-10,0,2,5,10,15,20,30$, 40 , and $60 \mathrm{~min}$ relative to the start of milking). The blood samples were processed as described above. A day later, mammary biopsies were taken, as described previously (Miller et al., 2006), from the left hindquarter in early lactation and from the right hindquarter in midlactation. Biopsies were then cut and processed as described by Bernier-Dodier et al. (2010). 
Table 1. Nutrient composition of the diets

\begin{tabular}{|c|c|c|c|c|}
\hline Item & $\begin{array}{c}\text { Late } \\
\text { lactation }\end{array}$ & Far-off & Pre-calving & $\begin{array}{c}\text { Early } \\
\text { lactation }\end{array}$ \\
\hline \multicolumn{5}{|l|}{ Ingredient ( $\%$, DM basis) } \\
\hline Grass hay & 10.3 & 65.9 & 24.0 & 4.6 \\
\hline Corn silage & 26.5 & 22.6 & 20.2 & 24.7 \\
\hline Grass silage & 24.5 & - & 21.1 & 24.5 \\
\hline Cracked corn & 23.5 & - & 11.3 & 19.6 \\
\hline Barley & - & - & - & 7.7 \\
\hline Soybean meal & 10.3 & 10.2 & 6.4 & 9.9 \\
\hline Canola meal & 0.59 & - & 0.56 & 0.56 \\
\hline Distillers grains (corn) & 0.88 & - & 0.84 & 0.84 \\
\hline Corn gluten meal $(60 \%)$ & 0.88 & - & 0.84 & 0.84 \\
\hline Micronized soybean & 0.59 & - & 0.56 & 0.56 \\
\hline Beet pulp & - & - & 12.8 & 3.7 \\
\hline Calcium carbonate & 0.3 & 0.2 & - & 0.5 \\
\hline Mineral and vitamin premix & $1.8^{1}$ & $1.2^{2}$ & $1.4^{2}$ & $2.0^{1}$ \\
\hline \multicolumn{5}{|l|}{ Nutrient composition } \\
\hline DM (\%) & 48.7 & 64.5 & 52.5 & 46.6 \\
\hline $\mathrm{CP}(\%)$ & 16.7 & 12.5 & 14.8 & 16.4 \\
\hline $\operatorname{ADF}(\%)$ & 19.4 & 32.8 & 27.5 & 20.8 \\
\hline NDF $(\%)$ & 30.9 & 51.6 & 42.5 & 32.0 \\
\hline $\mathrm{NFC}^{3}(\%)$ & 44.0 & 27.3 & 35.8 & 43.1 \\
\hline Ether extract $(\%)$ & 2.7 & 2.1 & 2.4 & 2.8 \\
\hline $\mathrm{NE}_{\mathrm{L}}^{4}(\mathrm{Mcal} / \mathrm{kg})$ & 1.60 & 1.42 & 1.58 & 1.60 \\
\hline
\end{tabular}

${ }^{1}$ Contains the following per kilogram of DM: $89.7 \mathrm{~g}$ of Ca, $49 \mathrm{~g}$ of $\mathrm{P}, 49 \mathrm{~g}$ of $\mathrm{Mg}, 140 \mathrm{~g}$ of $\mathrm{Na}, 82.6 \mathrm{~g}$ of $\mathrm{Cl}$, $280 \mathrm{~g}$ of NaCl, $14.3 \mathrm{~g}$ of K, $18 \mathrm{~g}$ of S, 1,992 $\mathrm{mg}$ of Fe, 1,840 $\mathrm{mg}$ of Mn, 2,720 $\mathrm{mg}$ of Zn, $447 \mathrm{mg}$ of Cu, $69.1 \mathrm{mg}$ of I, $59.6 \mathrm{mg}$ of Co, $20 \mathrm{mg}$ of Se, $271 \mathrm{mg}$ of Fl, 452,000 IU of vitamin A, 58,000 IU of vitamin D, and 2,692 IU of vitamin $\mathrm{E}$.

${ }^{2}$ Contains the following per kilogram of DM: $60 \mathrm{~g}$ of Ca, $60 \mathrm{~g}$ of P, $200 \mathrm{~g}$ of $\mathrm{Mg}, 53 \mathrm{~g}$ of Na, $10.6 \mathrm{~g}$ of Cl, $15.2 \mathrm{~g}$ of $\mathrm{K}, 16 \mathrm{~g}$ of S, 2,760 mg of Fe, 6,560 $\mathrm{mg}$ of $\mathrm{Mn}, 7,340 \mathrm{mg}$ of Zn, 1,570 $\mathrm{mg}$ of $\mathrm{Cu}, 160 \mathrm{mg}$ of I, $70 \mathrm{mg}$ of Co, $50 \mathrm{mg}$ of Se, 1,080,000 IU of vitamin A, 190,000 IU of vitamin D, and 12,560 IU of vitamin E.

${ }^{3} \mathrm{NFC}$ calculated as $100-[(\mathrm{NDF}-\mathrm{NDFCP})+\mathrm{CP}+$ ether extract + ash $](\mathrm{NRC}, 2001)$.

${ }^{4}$ Calculated according to the NRC (2001).

\section{Milk Composition}

Milk lactose, protein, and fat concentrations were determined by near-infrared spectrophotometry, and SCC was determined by an automatic cell counter in a commercial laboratory (Valacta Inc., Ste-Anne-deBellevue, QC, Canada). Milk BSA concentration was measured as described by Tremblay et al. (2009).

\section{Mammary Functional Capacity}

In this study, functional capacity was defined as the maximum volume of fluid that the mammary gland can contain and was an indirect measurement of the size of the gland (Davis et al., 1998). Functional capacity was determined by measuring the volume of milk harvested following a 24-h milking interval, which was presumed to lead to complete filling of the gland. This measurement was done at $70 \pm 1 \mathrm{DIM}$ at the $1900 \mathrm{~h}$ milking after the previous $0700 \mathrm{~h}$ milking had been skipped. After the end of milking, $20 \mathrm{IU}$ of oxytocin was injected, and the milking unit was put back in place to collect residual milk.

\section{Plasma Metabolites}

Plasma samples were assayed for urea, NEFA, glucose, and BHBA concentrations using the following commercial kits: Diagnostic Chemicals Ltd. urea assay kit (BioPacific Diagnostic Inc., Charlottetown, PE), NEFA-C test kit (Wako Chemicals GmbH, Neuss, Germany), glucose GOD-PAP assay kit (Roche GmbH, Mannheim, Germany), and BHBA reagent set (Pointe Scientific Inc., Canton, MI). These measurements were performed on plasma samples taken weekly from wk -12 to 12 , with 2 samples per week for wk 1 to 4 .

\section{Hormones}

Serum concentrations of progesterone and estradiol were measured using the Ovucheck plasma kit (Biovet Inc., St-Hyacinthe, QC, Canada) and the Estradiol Sensitive ELISA kit (DRG International Inc., Mountainside, NJ), respectively. Serum concentrations of prolactin (PRL) and growth hormone $(\mathbf{G H})$ were determined using double-antibody RIA, as described previously by Lapierre et al. (1990) and Petitclerc 
Table 2. Primers used during real-time PCR

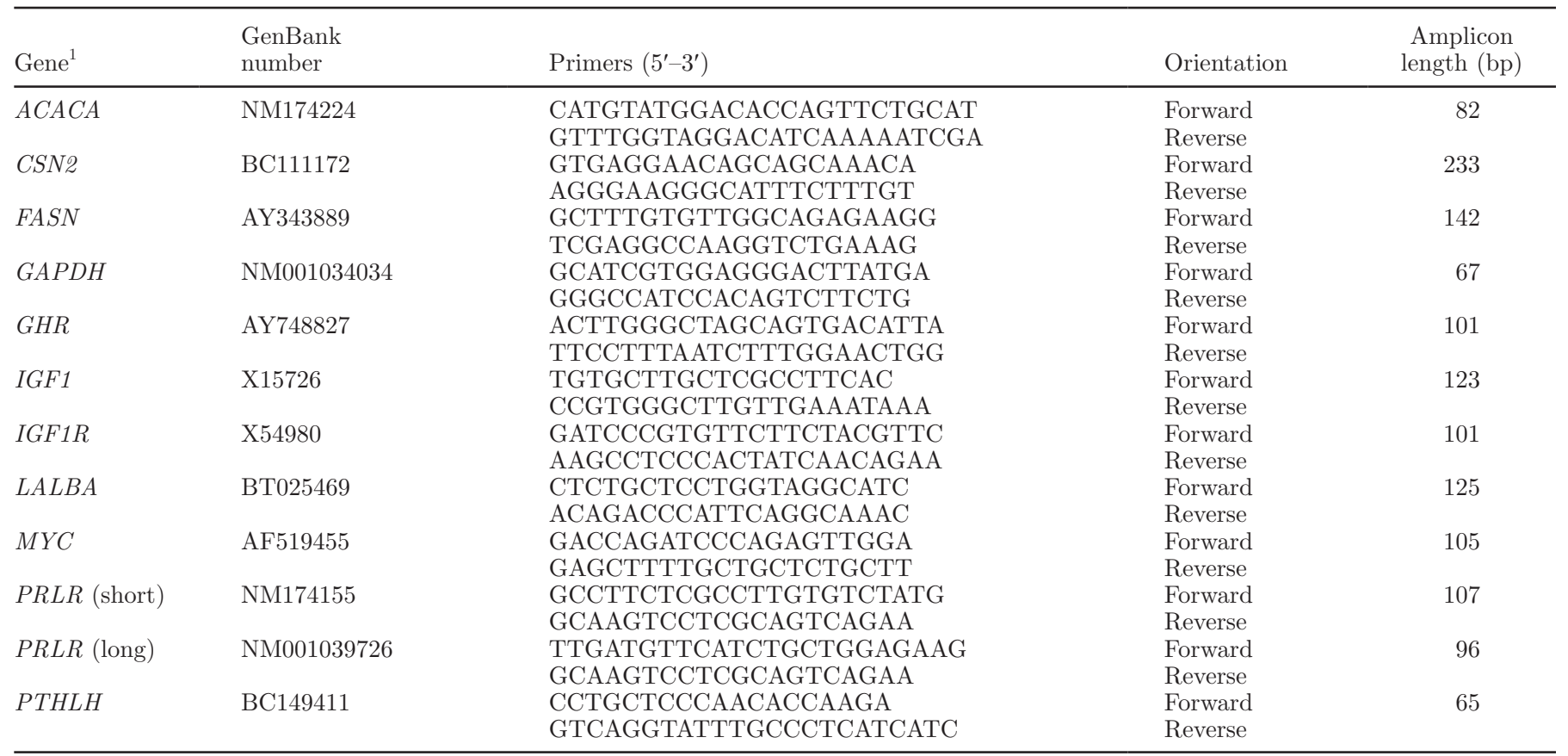

${ }^{1} A C A C A=$ acetyl-coenzyme A $(\mathrm{CoA})$ carboxylase $\alpha ; C S N 2=\beta-\mathrm{CN} ; F A S N=$ fatty acid synthase; $G H R=$ growth hormone receptor; IGF1R $=\mathrm{IGF} 1$ receptor; $L A L B A=\alpha-\mathrm{LA} ; M Y C=\mathrm{c}-\mathrm{Myc} ; P R L R$ (short) = prolactin receptor, short isoform; PRLR (long) = prolactin receptor, long isoform; PTHLH = parathyroid hormone-like hormone (PTHrP).

et al. (1987), respectively, with the following modification: incubation with the secondary antibody was done in the presence of polyethylene glycol for $2 \mathrm{~h}$. Anti-PRL antiserum, anti-GH antiserum, and antirabbit antibody were purchased from the National Hormone and Peptide Program (Torrance, CA). The inter- and intra-assay coefficients of variation were, respectively, 8.9 and $3.3 \%$ for PRL and 8.3 and $4.2 \%$ for GH. Measurements of progesterone and estradiol were performed on serum samples taken weekly from wk -12 to 1 , and measurements of $\mathrm{GH}$ were performed on samples taken weekly from wk -12 to 20 . Prolactin concentration was evaluated in prepartum samples taken weekly and in samples taken in early and midlactation at milking.

\section{Histology}

Mammary cell apoptosis and proliferation were evaluated on tissue sections (early and midlactation biopsies). Apoptosis was determined by terminal deoxynucleotidyl transferase 2 -deoxyuridine, $5^{\prime}$-triphosphate (dUTP) nick-end labeling (TUNEL) with the DeadEnd Colorimetric TUNEL System (Promega Corp., Madison, WI), and proliferation was assessed by Ki-67 antigen detection using the Histostain-Plus kit and a mouse anti-Ki-67 antibody (Invitrogen Corp., Burling- ton, ON, Canada). Those procedures were carried out as described previously (Bernier-Dodier et al., 2010).

\section{Real-Time PCR}

Extraction of total RNA from mammary biopsies (snap-frozen samples) was performed using RNeasy Lipid Tissue Mini Kit (Qiagen Inc., Mississauga, ON, Canada) according to the manufacturer's instructions. The extraction process included on-column digestion with the RNase-Free DNase Set (Qiagen Inc.) to eliminate possible DNA contamination. The concentration and purity of the RNA were evaluated by spectrophotometric analysis using an ND-1000 spectrophotometer (NanoDrop Technologies Inc., Wilmington, DE), and RNA integrity was assessed by visualization following agarose gel electrophoresis. Reverse transcription and real-time PCR were performed as described by BernierDodier et al. (2010), with the exception that the cDNA was diluted 1:10 instead of 1:50. Primer sequences are presented in Table 2 . The genes GAPDH, $\beta$-actin, and cyclophilin A were tested as potential housekeeping genes for the normalization of gene expression. The expression of the GAPDH gene showed less variability between the cows and was unaffected by the dry period length and the lactation stage and, therefore, was selected as the housekeeping gene. The normalized values 
obtained were presented as values relative to those of the CDP cows in early lactation.

\section{Statistical Analysis}

Statistical analyses were performed using the MIXED procedure of SAS (SAS Institute Inc., Cary, NC). Variables repeated in time were analyzed with the REPEATED statement. Time was used as a repeated effect, and cow was used as the subject. For the analysis of milk production and ECM, 305-d milk production during the previous lactation was used as a covariate. The amounts of PRL released into the blood at milking were calculated by determining the areas under the curves above baseline. Statistical analysis of the real-time PCR results was performed in accordance with the recommendations of User Bulletin \#2 for the ABI PRISM 7700 Sequence Detection System (December 11, 1997; Applied Biosystems Inc., Foster City, CA). Briefly, an ANOVA on $\log _{10}$ of the values normalized individually in relation to GAPDH was performed using the MIXED procedure of SAS with repeated measurements. Results were considered statistically significant when $P<0.05$. Energy-corrected milk was calculated with the following equation: ECM $=12.55 \times$ fat $(\mathrm{kg} / \mathrm{d})+7.39 \times$ protein $(\mathrm{kg} / \mathrm{d})+0.2595$ $\times$ milk $(\mathrm{kg} / \mathrm{d})$. This equation was derived from the Na- tional Research Council (NRC, 2001) equation for $\mathrm{NE}_{\mathrm{L}}$, considering a lactose concentration of $4.85 \%$ and setting the energy value of milk at $0.74 \mathrm{Mcal} / \mathrm{kg}$ of milk, as determined by Tyrrell and Reid (1965).

\section{RESULTS}

Dry period length averaged $31.9 \pm 1.0$ and $64.3 \pm$ $1.1 \mathrm{~d}$ for the SDP and CDP cows, respectively. The calving interval was similar for both groups (SDP: 391 $\pm 12 \mathrm{~d}$; CDP: $395 \pm 14 \mathrm{~d}$ ). Average 305-d milk production in the preceding lactation was also similar $(P$ $=0.58$ ) between treatments, namely $8,886 \pm 465$ and $9,356 \pm 508 \mathrm{~kg} / \mathrm{d}$ for the SDP and CDP cows, respectively. Thus, the cows from both groups produced similar amounts of milk before the drying-off of the CDP cows (wk -14 to -12 , before the CDP cows started on the dry-hay diet; $P=0.98$; Figure 1). Similarly, both groups produced milk with a similar composition $(P>$ 0.15) before the drying-off of the CDP cows.

Following parturition, the SDP cows had a lower milk yield than the CDP cows (wk 1 through 20; $P=$ 0.04 ), with the SDP and CDP cows averaging $35.2 \pm$ 1.2 and $38.7 \pm 1.0 \mathrm{~kg} / \mathrm{d}$, respectively. From wk 1 to 20, milk from the SDP and CDP cows had similar fat concentrations ( $P=0.22$; Table 3$)$, although the SDP cows tended to produce less fat $(P=0.06)$. During the

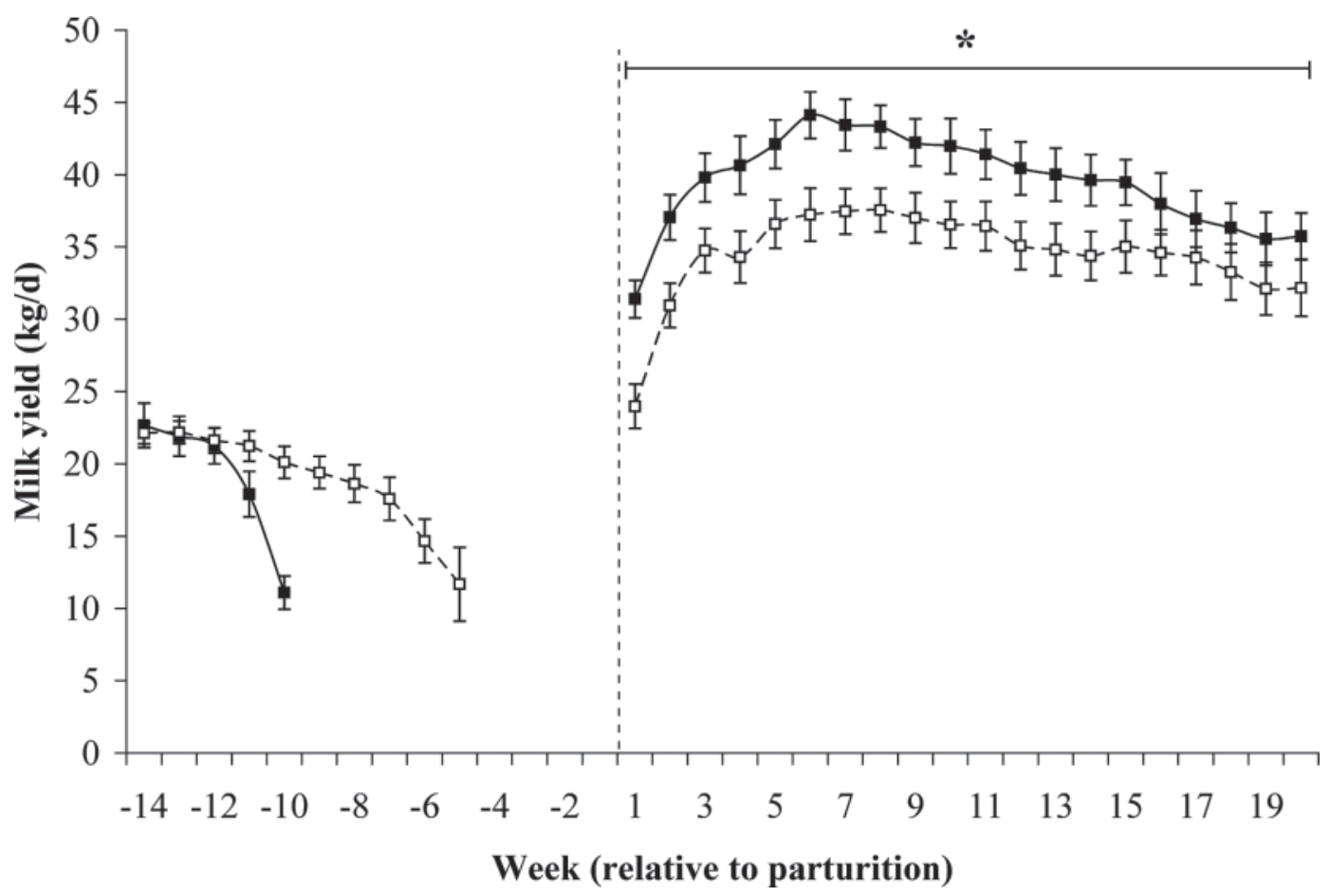

Figure 1. Daily milk yield of cows on either a short dry period (SDP; open symbols, dashed line) or a conventional dry period (CDP; closed symbols, solid line). Parturition is indicated by the vertical dashed line. From wk -9 to -6 , the SDP cows were still being milked and the CDP cows were already dry. The asterisk symbol denotes significant differences $(P<0.05)$ between the treatments. Data are presented as least squares means \pm standard error of the means. 
Table 3. Milk composition and daily ECM yield during the first 20 wk of lactation following a short dry period (SDP) or a conventional dry period $(\mathrm{CDP})^{1}$

\begin{tabular}{lccc}
\hline Variable & CDP & SDP & $P$-value \\
\hline Fat $(\%)$ & $3.65 \pm 0.08$ & $3.82 \pm 0.10$ & 0.22 \\
Fat yield (kg/d) & $1.43 \pm 0.05$ & $1.28 \pm 0.06$ & 0.06 \\
Protein (\%) & $3.14 \pm 0.05$ & $3.33 \pm 0.06$ & 0.03 \\
Protein yield (kg/d) & $1.23 \pm 0.04$ & $1.14 \pm 0.05$ & 0.19 \\
Lactose (\%) & $4.59 \pm 0.03$ & $4.57 \pm 0.04$ & 0.72 \\
Lactose yield (kg/d) & $1.81 \pm 0.06$ & $1.58 \pm 0.08$ & 0.03 \\
BSA (mg/mL) & $0.36 \pm 0.05$ & $0.20 \pm 0.05$ & 0.04 \\
ECM (kg/d) & $36.7 \pm 0.8$ & $34.0 \pm 0.9$ & 0.04 \\
\hline
\end{tabular}

${ }^{1}$ Data are presented as least squares means \pm standard error of the means.

same period, the SDP cows had higher milk protein concentrations than the CDP cows $(P=0.03$; Table 3$)$, whereas protein yields were similar in both groups $(P=$ $0.19)$. Milk lactose concentration was unaffected by dry period length $(P=0.72$; Table 3$)$, but the SDP cows yielded less lactose than the CDP cows $(P=0.03)$. The SDP cows produced less ECM than the CDP cows (wk 1 to $20 ; P=0.04$; Table 3 ). The dry period management strategy had no effect on SCC $(P=0.27$; data not shown), whereas milk BSA concentration was lower in the SDP cows than in the CDP cows $(P=0.04$; Table 3).

In both management strategies, the cows had similar DMI during most of the experiment (Figure 2) except the period when the CDP cows were already dry and were being fed the far-off diet while the SDP cows were still being milked and fed the late-lactation diet (wk -9 to -6$)$. During that period, the SDP cows had greater DMI compared with the CDP cows $(P=0.0001)$, with the SDP and CDP cows averaging $18.7 \pm 0.6$ and 12.3 $\pm 0.5 \mathrm{~kg} / \mathrm{d}$, respectively. The DMI increase in early lactation was similar for both groups (wk 1 to 4 ; $P=$ 0.19), but DMI tended to stabilize at a lower level for the SDP compared with the CDP cows, averaging 23.9 \pm 0.7 and $25.7 \pm 0.6 \mathrm{~kg} / \mathrm{d}$ for the SDP and CDP cows, respectively, from wk 5 to $20(P=0.07)$.

Feeding the CDP cows dry hay only for 1 wk at drying-off led to an important increase in blood NEFA and BHBA concentrations. Consequently, before the drying-off of the CDP cows (wk -12 to -10 ), the SDP cows had lower NEFA $(P=0.002$; Figure 3, panel A) and BHBA $(P=0.04$; Figure 3 , panel B) concentrations than the CDP cows. Plasma BHBA concentrations tended to be lower in the SDP cows than in the CDP cows in early lactation (wk 1 to 4; $P=0.07)$. Plasma concentrations of urea and glucose were unaffected by dry-period length $(P>0.15$; data not shown).

Mammary functional capacity, measured at $70 \pm$ 1 DIM, was not significantly affected when all cows were considered, with averages of $29.9 \pm 1.9 \mathrm{~L}$ in the
$\mathrm{SDP}$ cows and $32.4 \pm 1.6 \mathrm{~L}$ in the $\mathrm{CDP}$ cows $(P=$ $0.34)$. When only primiparous cows were considered, however, mammary functional capacity tended $(P=$ $0.14)$ to be lower in the SDP cows. The ratio of milk production to mammary functional capacity was identical for both groups, at $1.27 \pm 0.05(P=0.91)$.

Serum concentrations of $17 \beta$-estradiol (Figure 4, panel A) and progesterone (Figure 4, panel B) were similar in the SDP and CDP cows from wk -12 to wk 1 $(P>0.15)$. In wk -11 and -10 , the SDP cows tended to have lower GH compared with the CDP cows $(P=$ $0.08)$. However, GH was similar in both groups during the dry period and after parturition $(P>0.15$; Figure 5 , panel A). During the period when the CDP cows were dry while the SDP cows were still being milked (wk -9 to -6 ), PRL concentrations were higher in the SDP cows than in the CDP cows $(P=0.02$; Figure 5 , panel B), with the SDP and CDP cows averaging 9.24 \pm 1.35 and $4.60 \pm 1.19 \mathrm{ng} / \mathrm{mL}$, respectively. No differences were observed when both groups were milked or after the drying-off of the SDP cows $(P>0.15)$. Milking-induced PRL release (area under the curve above baseline) in early lactation (Figure 6, panel A) and midlactation (Figure 6, panel B) was unaffected by the dry period management strategy (early and midlactation: $P=0.47)$. However, $\mathrm{PRL}$ release was greater in early lactation than in midlactation $(P=0.01)$. Baseline PRL levels were similar in early lactation $(P$ $=0.27)$ but tended to be higher in the SDP cows compared with the CDP cows in midlactation $(P=0.11)$.

In early and midlactation, the cows in both groups had similar rates of mammary cell apoptosis (early lactation: $P=0.63$; midlactation: $P=0.53$; Figure 7 , panel A) and proliferation (early lactation: $P=0.28$; midlactation: $P=0.75$; Figure 7, panel B). Similarly, in early and midlactation, the dry-period management had no effect $(P>0.15)$ on mammary expression of the analyzed genes (Table 4). The expression of both PRL receptor (PRLR) isoforms decreased from early to midlactation (PRLR short: $P=0.002$; PRLR long: $P=0.001)$. 


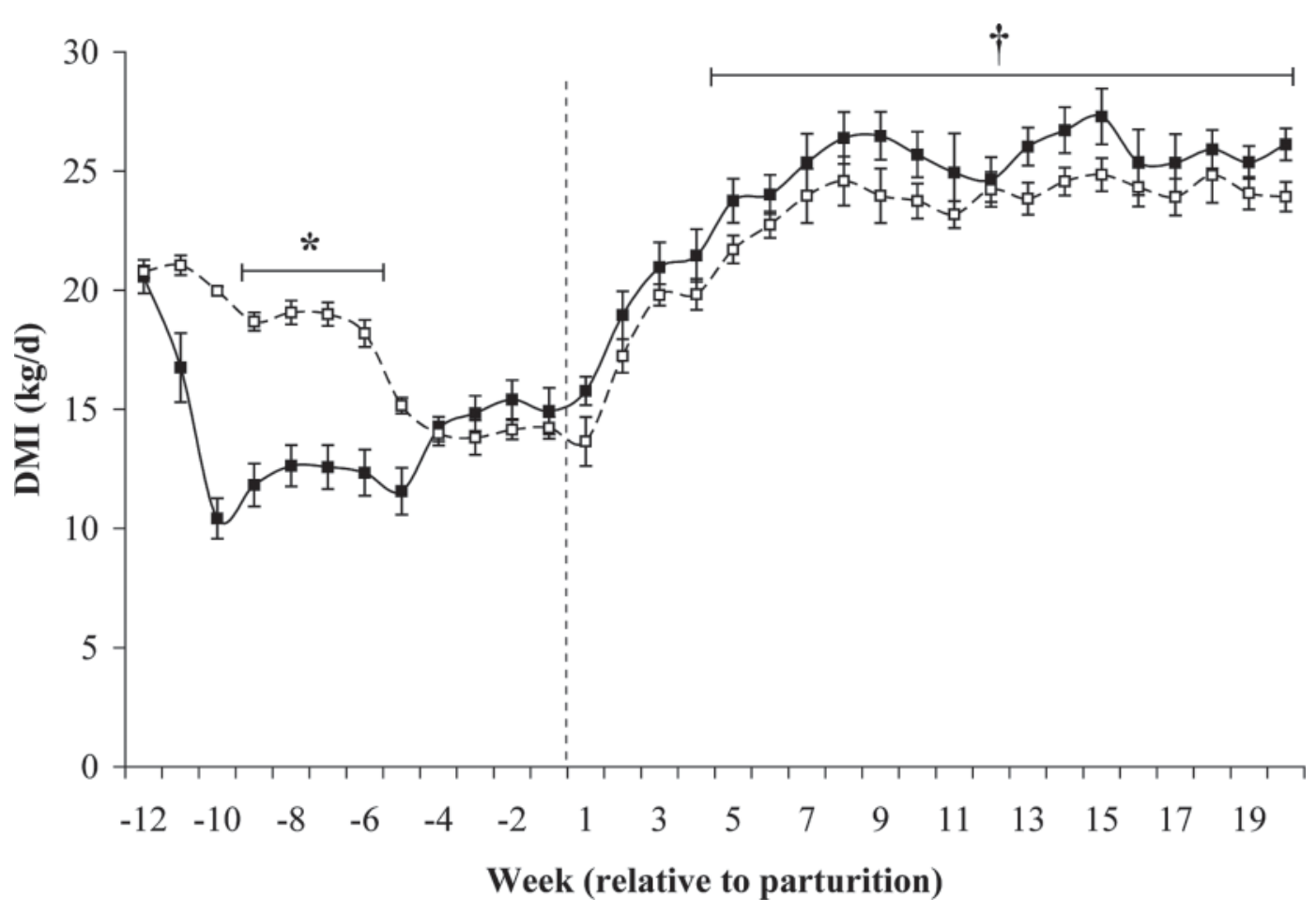

Figure 2. Dry matter intake of cows on either a short dry period (SDP; open symbols, dashed line) or a conventional dry period (CDP; closed symbols, solid line). Parturition is indicated by the vertical dashed line. From wk -9 to -6 , the SDP cows were still being milked and the CDP cows were already dry. The asterisk symbol denotes significant differences $(P<0.05)$ between the treatments, whereas the cross symbol denotes trends $(P<0.15)$. Data are presented as least squares means \pm standard error of the means.

\section{DISCUSSION}

In this study, an SDP management (32 d) decreased milk production by $9.2 \%$ (or $7.6 \%$ for ECM) during the first $20 \mathrm{wk}$ of the subsequent lactation as compared with a CDP management $(64 \mathrm{~d})$. This result is in accordance with studies that also reported a decrease in milk production following an SDP (Sørensen and Enevoldsen, 1991; Gulay et al., 2005; Rastani et al., 2005; Pezeshki et al., 2007; Church et al., 2008; Watters et al., 2008). For example, Sørensen and Enevoldsen (1991) showed that cows that underwent a 30-d dry period produced $12.8 \%$ less FCM than cows that underwent a 71-d dry period. Similarly, Rastani et al. (2005) reported a $10.7 \%$ loss following a 28 -d dry period when compared with a 56-d dry period. Results from Gulay et al. (2005) and Church et al. (2008) also showed an 18.9 and $10.0 \%$ milk yield decrease, respectively, following an SDP. In contrast, other studies reported no adverse effect of an SDP on milk production (Bachman, 2002; Gulay et al., 2003; Jolicoeur et al., 2009; Klusmeyer et al., 2009). Interestingly, the response to an SDP seems to vary depending on the parity of the cows. Annen et al. (2004b) showed that an SDP decreased the milk production of cows in their second lactation
$(13.2 \%)$ but had no effect on cows in their third or later lactation. Similar reports also showed that a decrease in milk production during the subsequent lactation was observed only in cows submitted to SDP management at the end of their first lactation (Pezeshki et al., 2007; Watters et al., 2008; Santschi et al., 2009). Therefore, some of the discrepancy in the literature concerning the milk yield response to an SDP is probably related to the parity of the animals used in those studies. In the present study, a high proportion of primiparous cows was present (especially in the SDP group) and, therefore, the negative effect observed on milk production was expected. Another source of variation might be the number of DIM considered. Our results and those of Klusmeyer et al. (2009) suggest that differences in milk production following dry periods of different lengths are less important as lactation progresses.

Decreasing the dry period length could have important effects on mammary cell renewal. The mammary cell proliferation rate reaches a peak during this period of the lactation cycle (Sorensen et al., 2006) and, as shown by Capuco et al. (1997), dry cows have higher mammary cell proliferation rates than do continuously milked cows. Thus, the dry period seems to be critical for the renewal of the mammary cells during late 
A

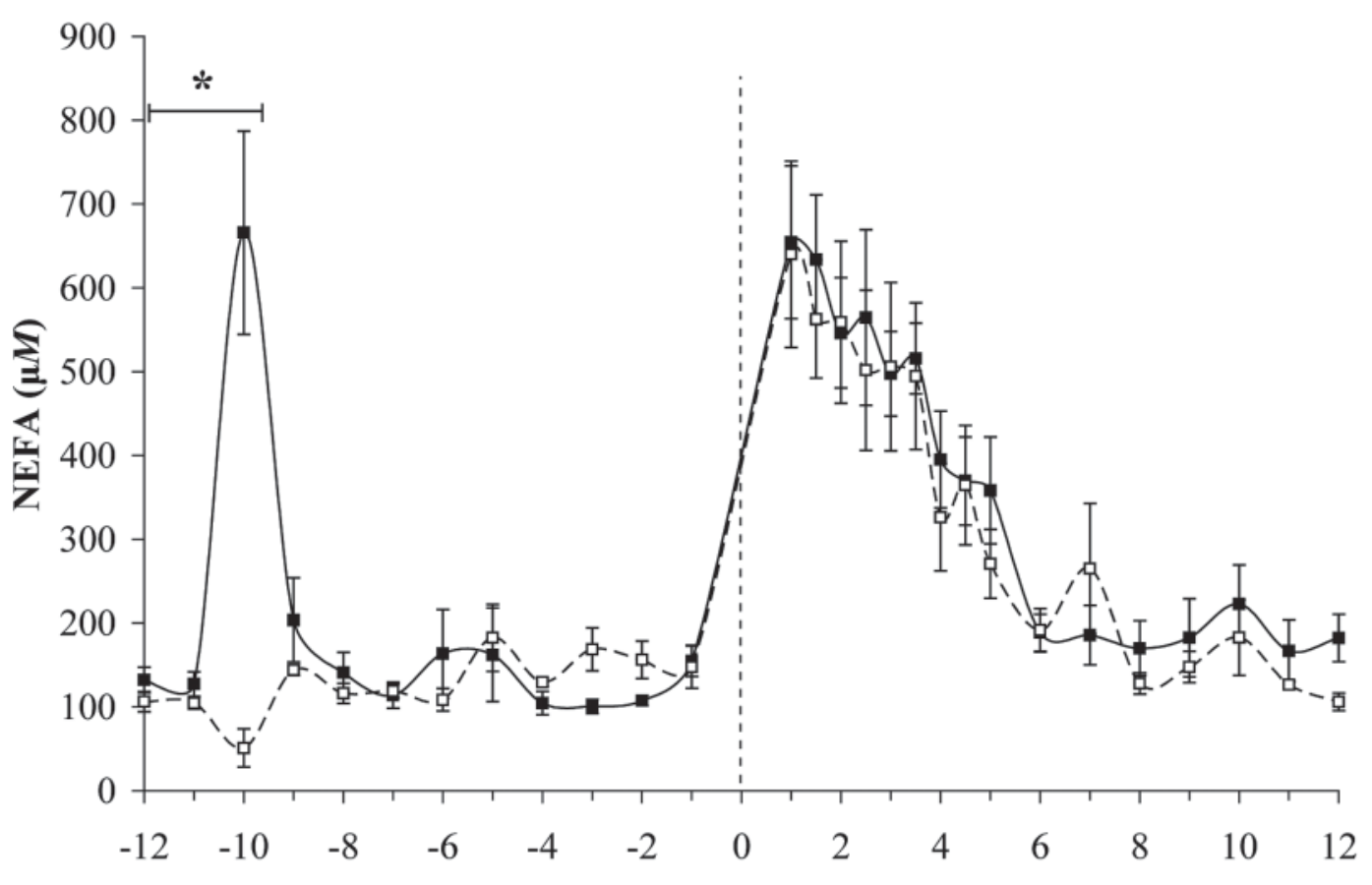

B

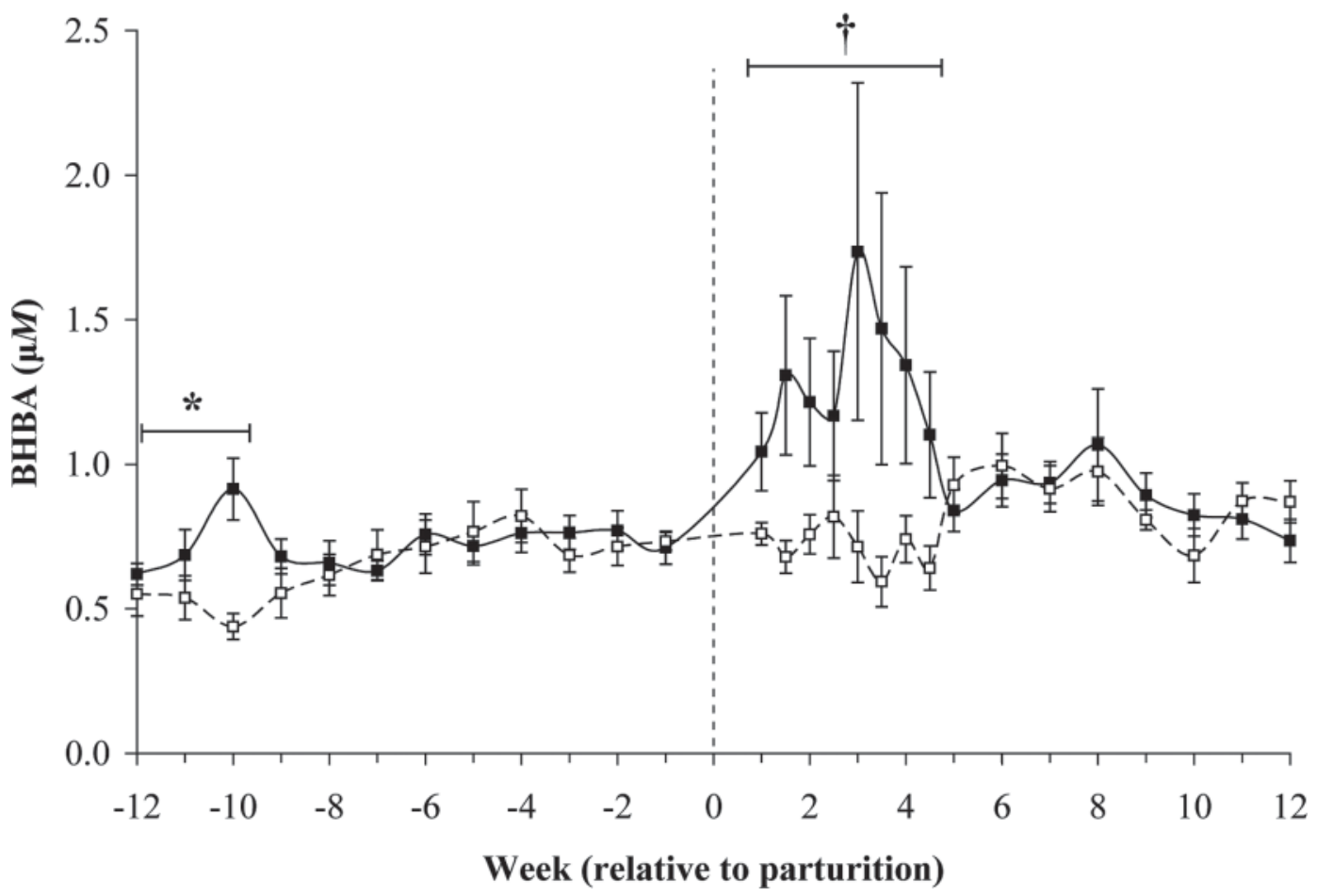

Figure 3. Nonesterified fatty acid (A) and BHBA (B) concentrations in cows on either a short dry period (SDP; open symbols, dashed line) or a conventional dry period (CDP; closed symbols, solid line). Parturition is indicated by the vertical dashed line. From wk -9 to -6 , the SDP cows were still being milked and the CDP cows were already dry. The asterisk symbol denotes significant differences $(P<0.05)$ between the treatments, whereas the cross symbol denotes trends $(P<0.15)$. Data are presented as least squares means \pm standard error of the means. 
A

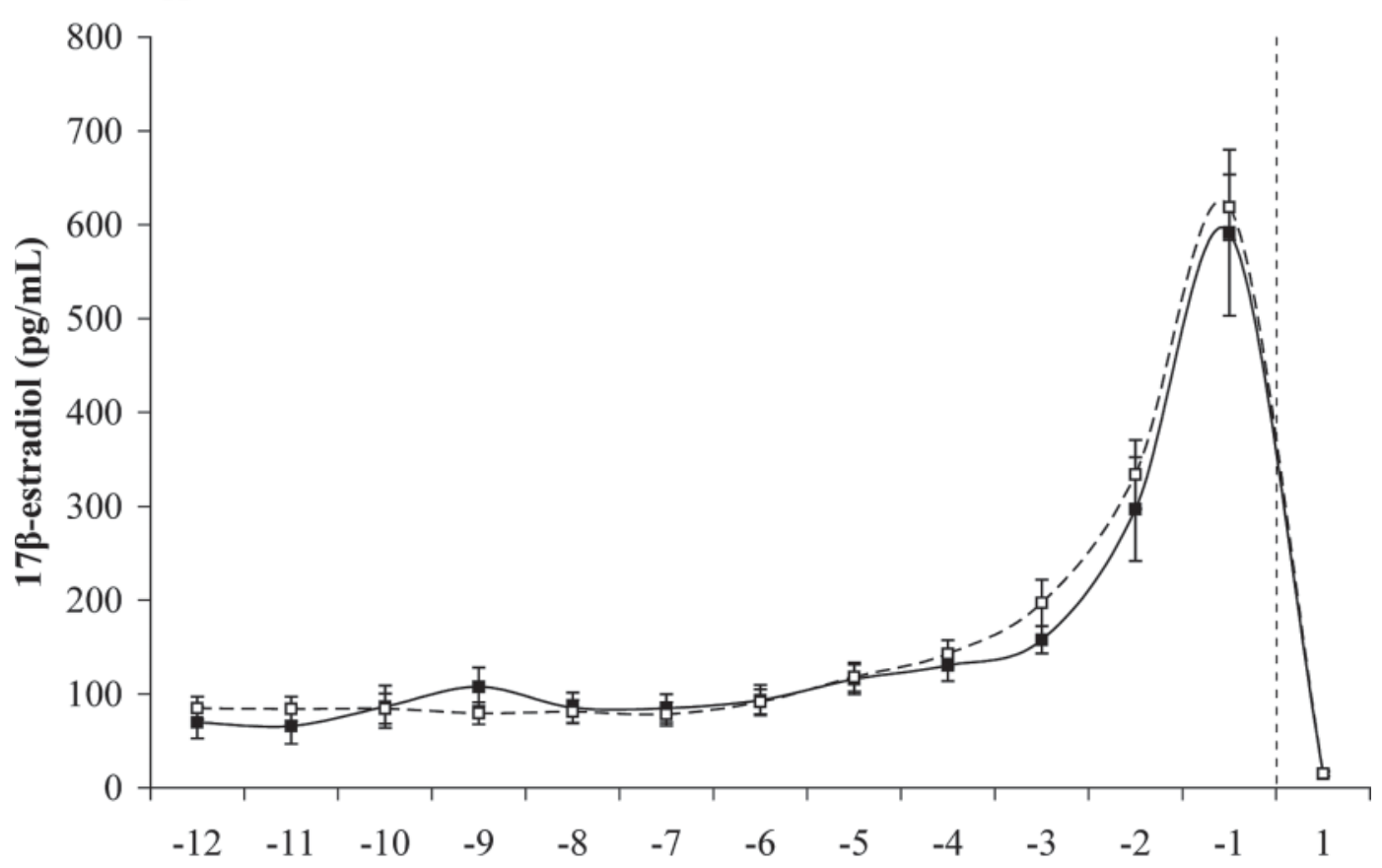

B

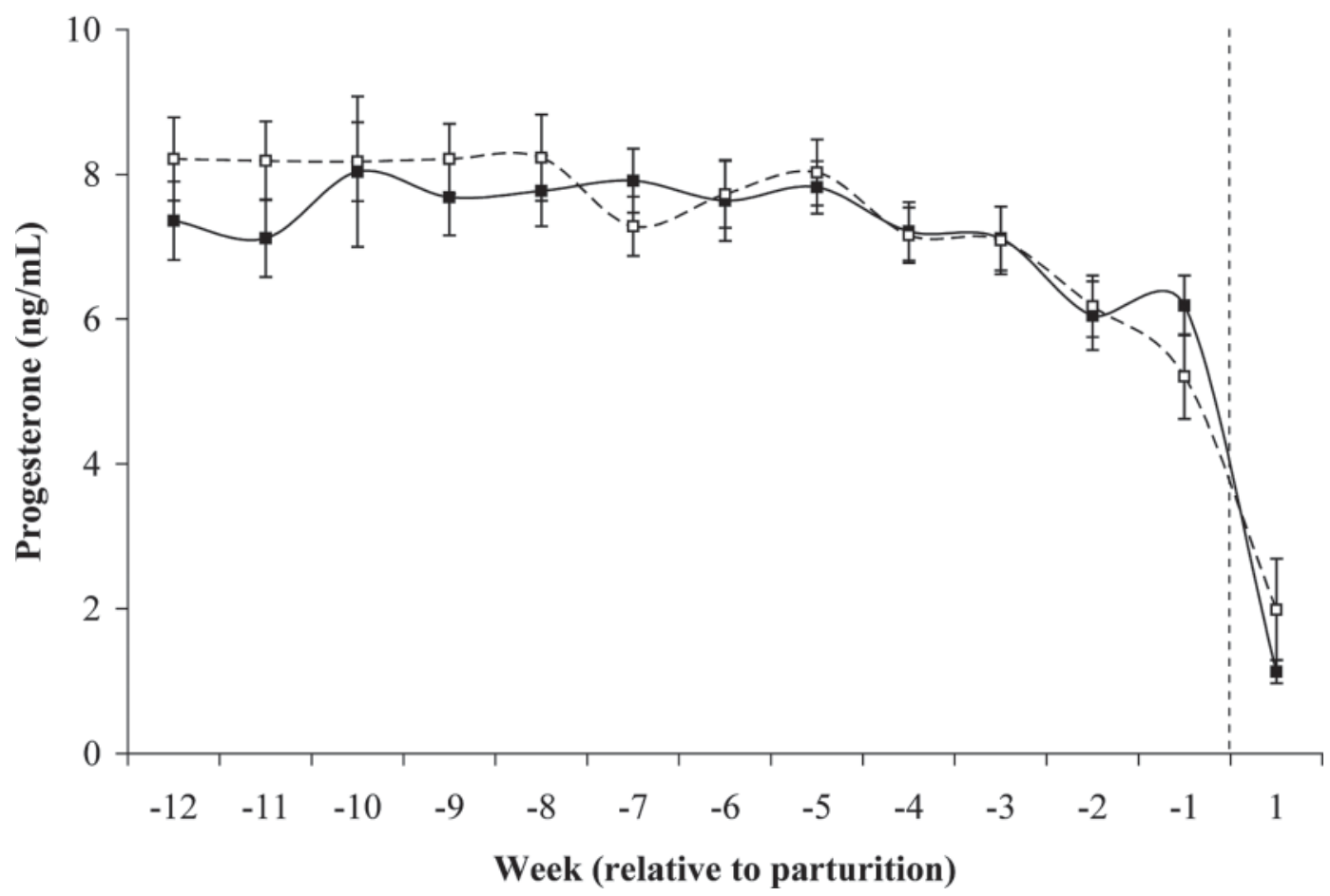

Figure 4. $17 \beta$-estradiol (A) and progesterone (B) concentrations in cows on either a short dry period (open symbols, dashed line) or a conventional dry period (closed symbols, solid line). Parturition is indicated by the vertical dashed line. From wk -9 to -6 , the SDP cows were still being milked and the CDP cows were already dry. Concentrations of both $17 \beta$-estradiol and progesterone were unaffected by the dry period management strategy $(P>0.15)$. Data are presented as least squares means \pm standard error of the means. 
A

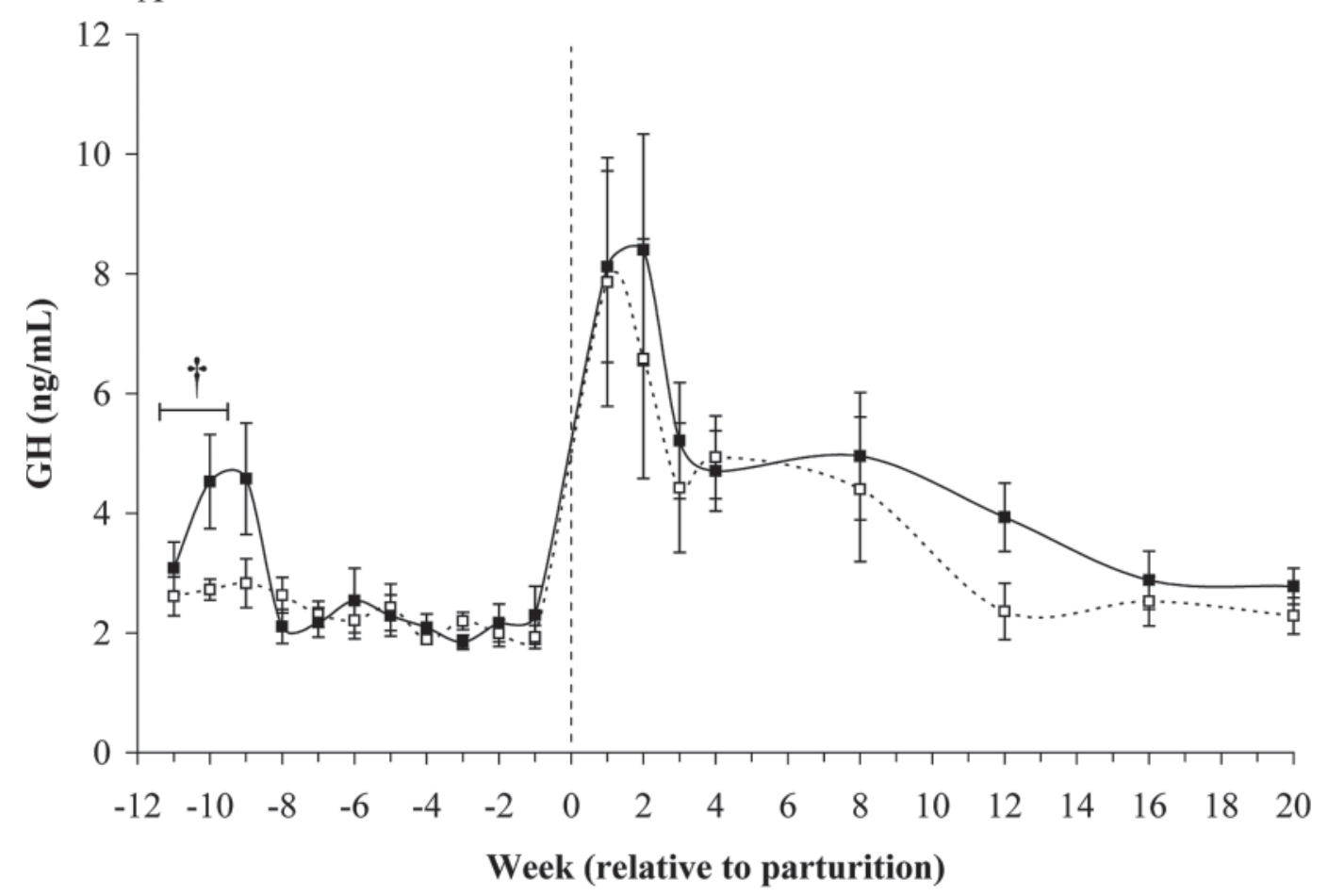

B

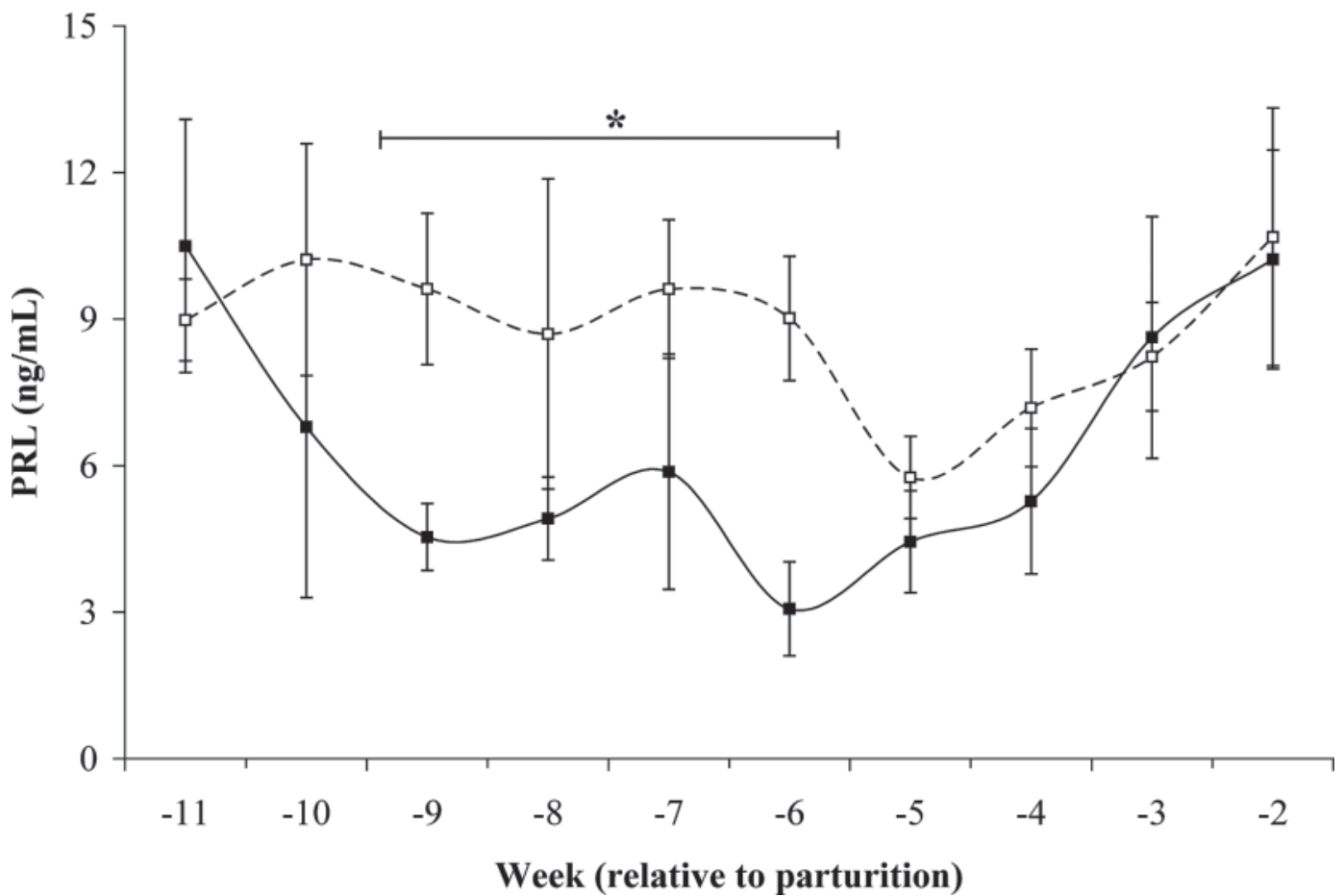

Figure 5. Growth hormone (GH; A) and prolactin (PRL; B) concentrations in cows on either a short dry period (SDP; open symbols, dashed line) or a conventional dry period (CDP; closed symbols, solid line). Parturition is indicated by the vertical dashed line. From wk -9 to -6 the SDP cows were still being milked and the CDP cows were already dry. The asterisk symbol denotes significant differences $(P<0.05)$ between the treatments, whereas the cross symbol denotes trends $(P<0.15)$. Data are presented as least squares means \pm standard error of the means. 

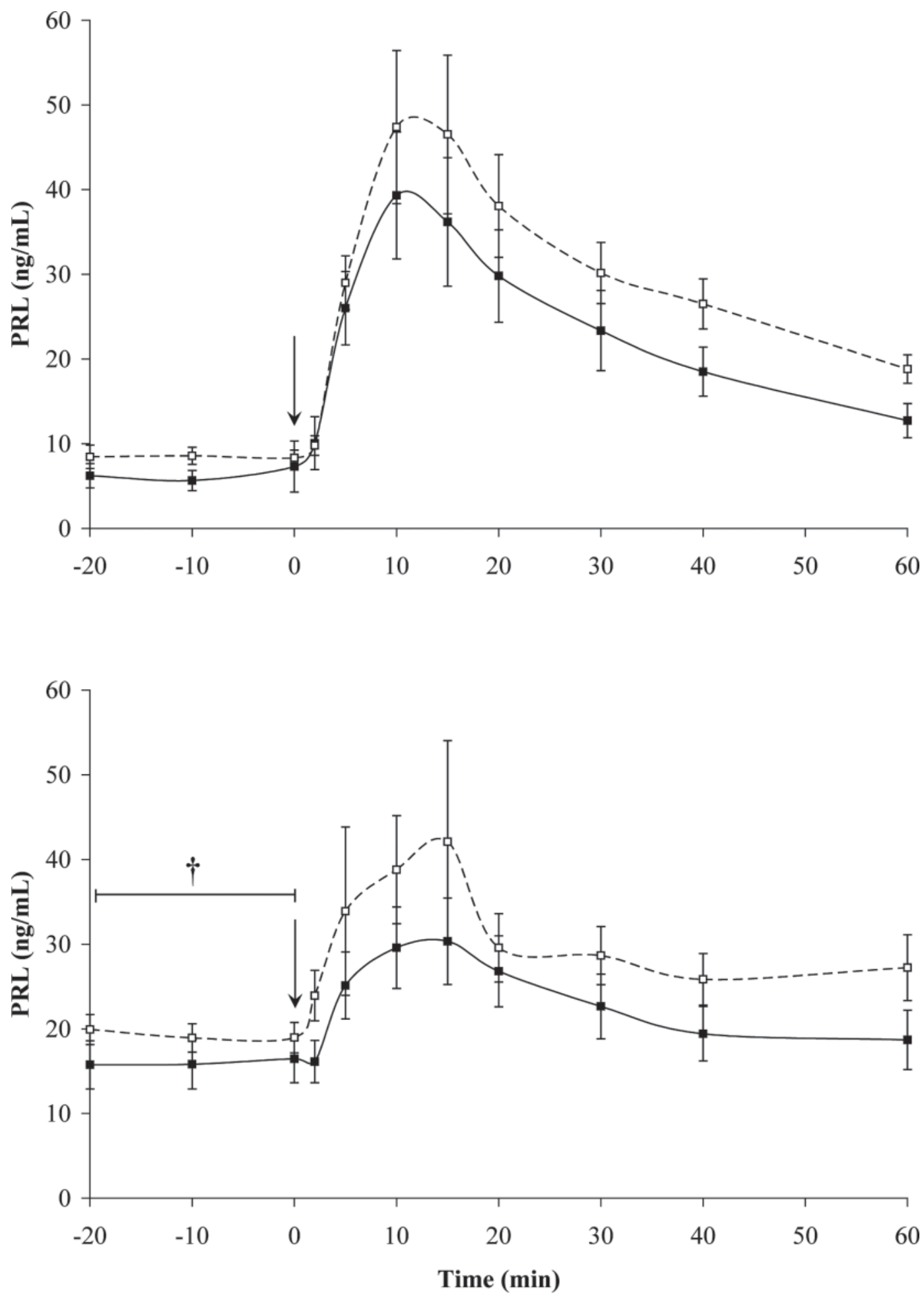

Figure 6. Milking-induced release of prolactin (PRL) in early lactation (A) and midlactation (B) in cows on either a short dry period (SDP; open symbols, dashed line) or a conventional dry period (CDP; closed symbols, solid line). The arrow indicates the start of milking. The cross symbol denotes trends $(P<0.15)$ between the treatments. Data are presented as least squares means \pm standard error of the means. 
A

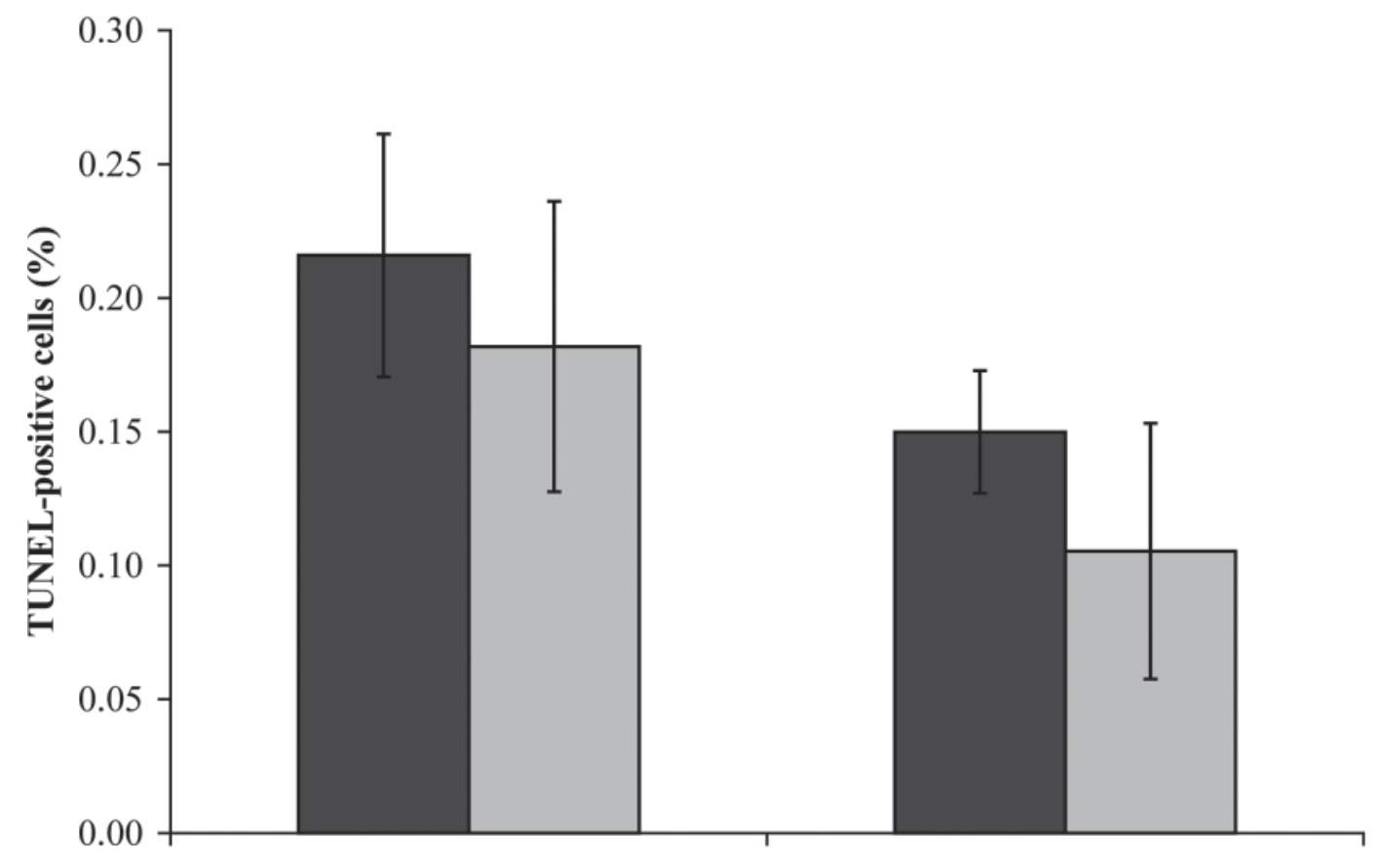

B

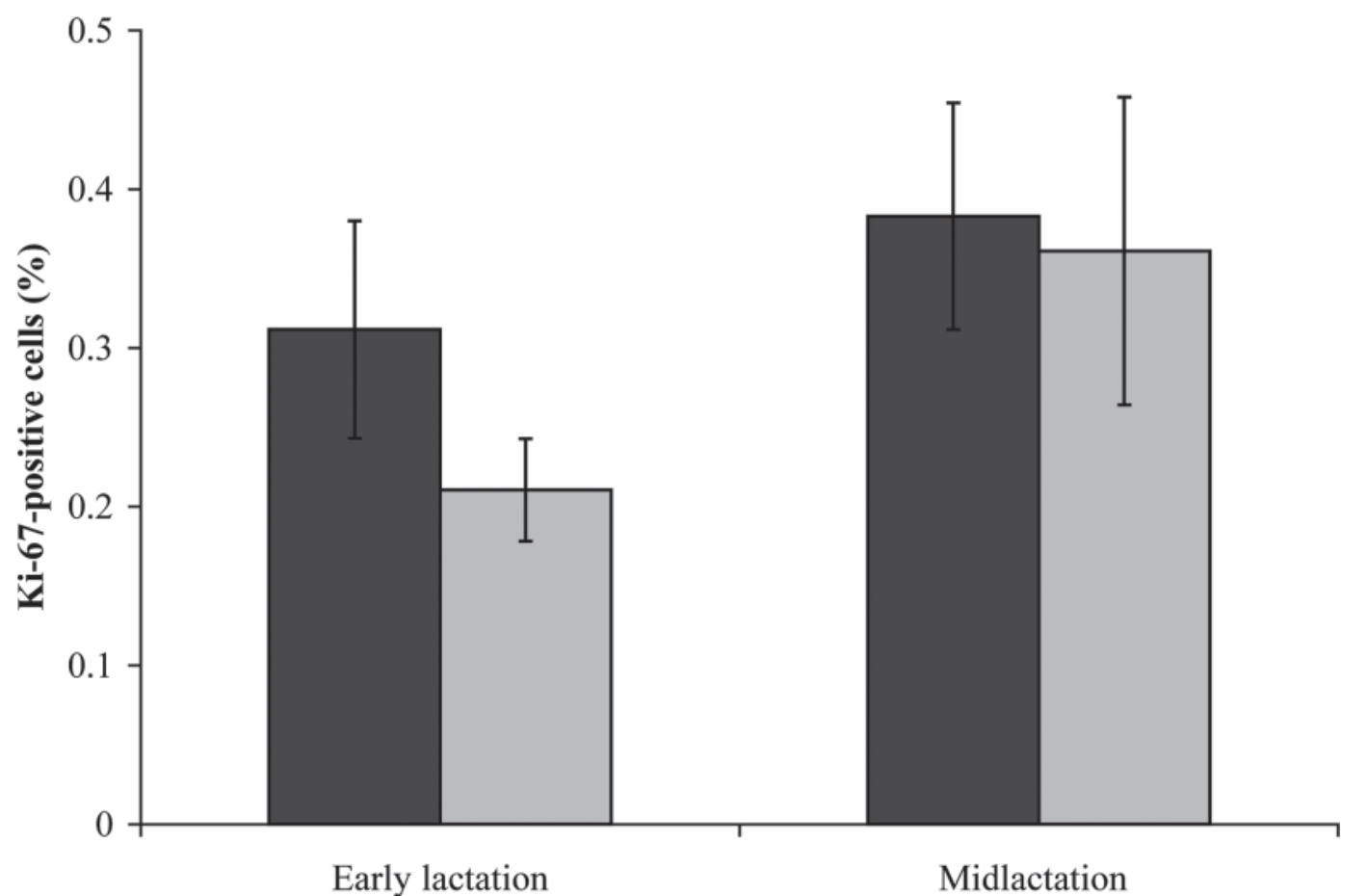

Figure 7. Mammary cell apoptosis (A) and proliferation (B) in early and midlactation cows on either a short dry period (gray bars) or a conventional dry period (black bars). Apoptosis was measured by terminal deoxynucleotidyl transferase $2^{\prime}$-deoxyuridine, $5^{\prime}$-triphosphate (dUTP) nick-end labeling (TUNEL), and proliferation was evaluated by Ki-67 labeling. No differences were obtained between the 2 groups $(P>0.15)$. Data are presented as the percentage of labeled cells compared with the total number of cells and as least squares means \pm standard error of the means. 
Table 4. Gene expression in the mammary glands of lactating cows following a short dry period (SDP) or a conventional dry period (CDP) ${ }^{1}$

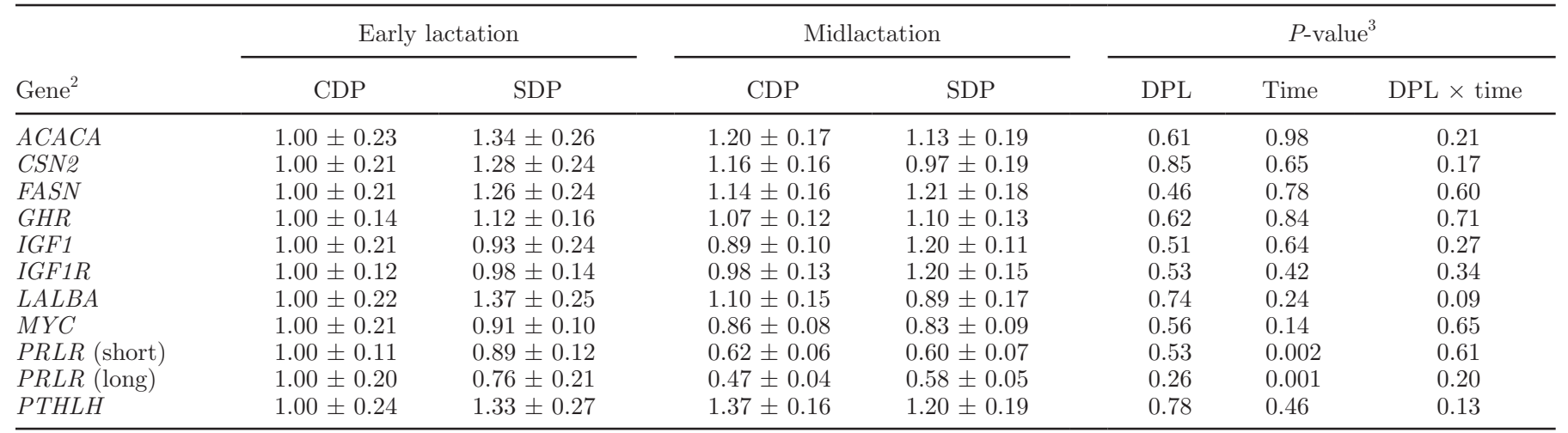

${ }^{1}$ Mammary biopsies were taken in early and midlactation on the left and right hindquarters, respectively. All values were normalized with $G A P D H$ cDNA and expressed as values relative to those of the CDP cows in early lactation. Data are presented as least squares means \pm standard error of the means.

${ }^{2} A C A C A=$ acetyl-coenzyme A $(\mathrm{CoA})$ carboxylase $\alpha ; C S N 2=\beta$-CN; $F A S N=$ fatty acid synthase; GHR $=$ growth hormone receptor; IGF1R $=\mathrm{IGF} 1$ receptor; $L A L B A=\alpha-\mathrm{LA} ; M Y C=\mathrm{c}-\mathrm{Myc} ; P R L R$ (short) = prolactin receptor, short isoform; PRLR (long) = prolactin receptor, long isoform; PTHLH = parathyroid hormone-like hormone (PTHrP).

${ }^{3}$ ANOVA tested for effects of dry period length (DPL), time (early vs. midlactation), and interaction between DPL and time (DPL $\times$ time)

gestation. The cause of this positive effect is currently unknown, but alterations in the hormonal milieu could be involved in this process.

The SDP cows had higher PRL concentrations than the CDP cows when the former were still being milked but the latter were already dry (wk -9 to -6 ). Prolactin is a key regulator of mammary development and lactation, although its function in cow mammogenesis is still unclear (Collier et al., 1993; Trott et al., 2008). Nevertheless, studies on the effect of long-day photoperiod and heat stress suggest a possible effect of this hormone on dry period mammary gland renewal. Indeed, it was shown that long-day photoperiod (Auchtung et al., 2005; Velasco et al., 2008) and heat stress (do Amaral et al., 2009; Tao et al., 2010) during the dry period had negative effects on milk production during the subsequent lactation. Interestingly, both treatments increased PRL concentrations and decreased mammary growth (Auchtung et al., 2005; do Amaral et al., 2009, 2010; Tao et al., 2010). Moreover, long-day photoperiod decreased mammary gland expression of the PRLR gene (Auchtung et al., 2005). Dahl (2008) proposed that altered PRL signaling during the dry period could affect mammary growth and subsequent milk yield. Consequently, milk production loss following an SDP could be linked to a high PRL concentration during late gestation, although in the present experiment no further effect was observed on mammary expression of the PRLR gene in early and midlactation.

The dry period management strategy had no effect on milking-induced PRL release or basal PRL concentrations during the subsequent lactation. The role of PRL in cow galactopoiesis is a matter of debate, although recent evidence supports a positive role in this process (Lacasse et al., 2011). However, results from the present study indicate that milking-induced PRL release is not likely involved in the negative effect of SDP management on milk production.

Sangsritavong et al. (2002) reported that the clearance rates of exogenous $17 \beta$-estradiol and progesterone are higher in lactating cows than in nonlactating cows. Consequently, a longer lactation could result in an alteration in the concentrations of these hormones during late gestation. Because both estrogen and progesterone are involved in the development of the mammary gland, such effects could have an important effect on mammary cell renewal. However, as reported previously (Gümen et al., 2005) and in our experiment, SDP management did not affect the concentration of these hormones when compared with a CDP. Therefore, $17 \beta$-estradiol and progesterone are probably not involved in the decreased milk yield following an SDP.

After the dry period, milk BSA concentration was lower in the SDP cows than in the CDP cows. One critical change occurring during lactogenesis is the closure of the tight junctions (Nguyen et al., 2001). Milk BSA concentration is often used as an indicator of tight junction permeability (Stelwagen et al., 1994; Tremblay et al., 2009; Bernier-Dodier et al., 2010); therefore, the low milk BSA in the SDP cows suggests that their mammary tight junctions were closed in early lactation and that SDP management did not impair the later stage of lactogenesis.

During lactation, the number and activity of secretory cells determine the level of milk production (Capuco et al., 2001). Annen et al. (2007) observed that, 
in early lactation, CM glands have a lower proportion of secretory alveoli than CDP glands, suggesting that the presence of resting alveoli may explain the negative effect of dry period omission. However, in the present study, gene expression of a milk protein ( $\beta-\mathrm{CN}$ gene) as well as proteins involved in the synthesis of milk components ( $\alpha$-lactalbumin, fatty acid synthase, and acetyl-coenzyme A carboxylase genes) were unaffected by the dry period management strategy. Accordingly, the ratio of milk production to mammary gland functional capacity was identical for both groups. Apoptosis and proliferation rates in early and midlactation were also similar between the SDP cows and the CDP cows. Mammary cell activity and postpartum regulation of cell number seemed unaffected by dry period length and are, therefore, unlikely involved in the decrease in milk production following an SDP.

Shortening the dry period may affect mammary gland renewal. Indeed, Capuco et al. (1997) showed that the proportion of epithelial cells in dry glands was higher than in the lactating glands during the last week of gestation when compared with CM glands. Although the number of secretory cells present in the mammary gland was not measured in the present study, the functional capacity, which is an indirect estimation of this variable, was measured at 70 DIM and tended to be higher in the CDP cows than in the SDP cows, although only in primiparous animals. Given our results, the most likely explanation for the lower milk production after an SDP is an incomplete mammary gland renewal during the dry period, leading to a lower epithelial cell number in the SDP cows as compared with the CDP cows. An inadequate hormonal milieu, possibly related to the elevated PRL in late gestation, could be responsible for this effect. Nonetheless, these hypotheses need to be confirmed by more direct evidence.

A high milk yield at drying-off increases the risk of IMI at calving by $77 \%$ for every $5 \mathrm{~kg}$ of milk produced above $12.5 \mathrm{~kg}$ at drying-off (Rajala-Schultz et al., 2005). However, feeding only dry hay to the CDP cows during the week of their drying-off, in an attempt to rapidly decrease their milk production, led to an important increase in blood plasma concentrations of NEFA and BHBA. High NEFA concentrations decrease several activities of the lymphocytes in vitro (Ster et al., 2010). Therefore, the anticipated benefits associated with the rapid lowering of milk yield induced by feeding only dry hay for a limited period of time are possibly undermined by a decrease in immune cell activities due to the increased plasma concentrations of NEFA.

In conclusion, the SDP management strategy in the present experiment decreased postpartum milk production. This effect may be related to a decreased mammary cell growth during the dry period. If this hypothesis is confirmed, approaches that would accelerate mammary gland renewal or mammary cell growth during the dry period might overcome the negative effect of a short dry period on the subsequent lactation.

\section{ACKNOWLEDGMENTS}

The authors thank Jasmin Brochu, Lisette St-James, Chrystiane Plante, and Guylaine Demers for providing technical assistance, the dairy barn staff for taking care of the cows, and Steve Méthot for performing the statistical analysis (all from Agriculture and Agri-Food Canada, Sherbrooke, QC, Canada). Also, we thank the National Hormone and Peptide Program and A. F. Parlow for providing the GH and PRL antisera. This research was financially supported by the Action concertée Novalait-FQRNT-MAPAQ-AAC (Quebec, QC, Canada).

\section{REFERENCES}

Annen, E. L., R. J. Collier, M. A. McGuire, and J. L. Vicini. 2004a. Effects of dry period length on milk yield and mammary epithelial cells. J. Dairy Sci. 87(Suppl. 1):E66-E76.

Annen, E. L., R. J. Collier, M. A. McGuire, J. L. Vicini, J. M. Ballam, and M. J. Lormore. 2004b. Effect of modified dry period lengths and bovine somatotropin on yield and composition of milk from dairy cows. J. Dairy Sci. 87:3746-3761.

Annen, E. L., A. C. Fitzgerald, P. C. Gentry, M. A. McGuire, A. V. Capuco, L. H. Baumgard, and R. J. Collier. 2007. Effect of continuous milking and bovine somatotropin supplementation on mammary epithelial cell turnover. J. Dairy Sci. 90:165-183.

Auchtung, T. L., A. G. Rius, P. E. Kendall, T. B. McFadden, and G. E. Dahl. 2005. Effects of photoperiod during the dry period on prolactin, prolactin receptor, and milk production of dairy cows. J. Dairy Sci. 88:121-127.

Bachman, K. C. 2002. Milk production of dairy cows treated with estrogen at the onset of a short dry period. J. Dairy Sci. 85:797-803.

Bachman, K. C., and M. L. Schairer. 2003. Invited review: Bovine studies on optimal lengths of dry periods. J. Dairy Sci. 86:30273037.

Bernier-Dodier, P., L. Delbecchi, G. F. Wagner, B. G. Talbot, and P. Lacasse. 2010. Effect of milking frequency on lactation persistency and mammary gland remodeling in mid-lactation cows. J. Dairy Sci. 93:555-564.

Canadian Council on Animal Care. 1993. Guide to the Care and Use of Experimental Animals, Vol. 1. 2nd ed. E. D. Olfert, B. M. Cross, and A. A. McWilliam, ed. Canadian Council on Animal Care, Ottawa, Ontario, Canada.

Capuco, A. V., R. M. Akers, and J. J. Smith. 1997. Mammary growth in Holstein cows during the dry period: Quantification of nucleic acids and histology. J. Dairy Sci. 80:477-487.

Capuco, A. V., D. L. Wood, R. Baldwin, K. McLeod, and M. J. Paape. 2001. Mammary cell number, proliferation, and apoptosis during a bovine lactation: Relation to milk production and effect of bST. J. Dairy Sci. 84:2177-2187.

Church, G. T., L. K. Fox, C. T. Gaskins, D. D. Hancock, and J. M. Gay. 2008. The effect of a shortened dry period on intramammary infections during the subsequent lactation. J. Dairy Sci. 91:4219-4225.

Collier, R. J., M. F. McGrath, J. C. Byatt, and L. L. Zurfluh. 1993. Regulation of bovine mammary growth by peptide hormones: Involvement of receptors, growth factors and binding proteins. Livest. Prod. Sci. 35:21-33.

Dahl, G. E. 2008. Effects of short day photoperiod on prolactin signaling in dry cows: A common mechanism among tissues and environments? J. Anim. Sci. 86(Suppl.):10-14. 
Davis, S. R., V. C. Farr, P. J. Copeman, V. R. Carruthers, C. H Knight, and K. Stelwagen. 1998. Partitioning of milk accumulation between cisternal and alveolar compartments of the bovine udder: Relationship to production loss during once daily milking. J. Dairy Res. 65:1-8.

do Amaral, B. C., E. E. Connor, S. Tao, J. Hayen, J. Bubolz, and G. E. Dahl. 2009. Heat-stress abatement during the dry period: Does cooling improve transition into lactation? J. Dairy Sci. 92:59885999.

do Amaral, B. C., E. E. Connor, S. Tao, J. Hayen, J. Bubolz, and G. E. Dahl. 2010. Heat stress abatement during the dry period influences prolactin signaling in lymphocytes. Domest. Anim. Endocrinol. 38:38-45.

Fitzgerald, A. C., E. L. Annen-Dawson, L. H. Baumgard, and R. J. Collier. 2007. Evaluation of continuous lactation and increased milking frequency on milk production and mammary cell turnover in primiparous Holstein cows. J. Dairy Sci. 90:5483-5489.

Gulay, M. S., M. J. Hayen, K. C. Bachman, T. Belloso, M. Liboni, and H. H. Head. 2003. Milk production and feed intake of Holstein cows given short (30-d) or normal (60-d) dry periods. J. Dairy Sci. 86:2030-2038

Gulay, M. S., M. J. Hayen, H. H. Head, C. J. Wilcox, and K. C Bachman. 2005. Milk production from Holstein half udders after concurrent thirty- and seventy-day dry periods. J. Dairy Sci. 88:3953-3962

Gümen, A., R. R. Rastani, R. R. Grummer, and M. C. Wiltbank. 2005. Reduced dry periods and varying prepartum diets alter postpartum ovulation and reproductive measures. J. Dairy Sci. 88:2401-2411.

Jolicoeur, M. S., A. F. Brito, D. Pellerin, D. Lefebvre, R. Berthiaume, and C. L. Girard. 2009. Short dry period management improves peripartum ruminal adaptation in dairy cows. J. Dairy Sci. 92(ESuppl. 1):333.

Klusmeyer, T. H., A. C. Fitzgerald, A. C. Fabellar, J. M. Ballam, R. A. Cady, and J. L. Vicini. 2009. Effect of recombinant bovine somatotropin and a shortened or no dry period on the performance of lactating dairy cows. J. Dairy Sci. 92:5503-5511.

Lacasse, P., V. Lollivier, R. M. Bruckmaier, Y. R. Boisclair, G. F. Wagner, and M. Boutinaud. 2011. Effect of the prolactin-release inhibitor quinagolide on lactating dairy cows. J. Dairy Sci. 94:1302-1309.

Lapierre, H., D. Petitclerc, G. Pelletier, L. Delorme, P. Dubreuil, J. Morisset, P. Gaudreau, Y. Couture, and P. Brazeau. 1990. Effect of human growth hormone-releasing factor and(or) thyrotropinreleasing factor on hormone concentrations in dairy calves. J. Anim. Sci. 68:2436-2449.

Madsen, T. G., M. O. Nielsen, J. B. Andersen, and K. L. Ingvartsen. 2008. Continuous lactation in dairy cows: Effect on milk production and mammary nutrient supply and extraction. J. Dairy Sci. 91:1791-1801.

Miller, N., L. Delbecchi, D. Petitclerc, G. F. Wagner, B. G. Talbot, and P. Lacasse. 2006. Effect of stage of lactation and parity on mammary gland cell renewal. J. Dairy Sci. 89:4669-4677.

NRC. 2001. Nutrient Requirements of Dairy Cattle. 7th rev. ed. Natl. Acad. Sci., Washington, DC.

Newman, K. A., P. J. Rajala-Schultz, F. J. DeGraves, and J. Lakritz. 2010. Association of milk yield and infection status at dry-off with intramammary infections at subsequent calving. J. Dairy Res. 77:99-106.

Nguyen, D. A., A. F. Parlow, and M. C. Neville. 2001. Hormonal regulation of tight junction closure in the mouse mammary epithelium during the transition from pregnancy to lactation. J. Endocrinol 170:347-356.

Petitclerc, D., G. Pelletier, H. Lapierre, P. Gaudreau, Y. Couture, P. Dubreuil, J. Morisset, and P. Brazeau. 1987. Dose response of two synthetic human growth hormone-releasing factors on growth hormone release in heifers and pigs. J. Anim. Sci. 65:996-1005.

Pezeshki, A., J. Mehrzad, G. R. Ghorbani, H. R. Rahmani, R. J. Collier, and C. Burvenich. 2007. Effects of short dry periods on performance and metabolic status in Holstein dairy cows. J. Dairy Sci. 90:5531-5541

Rajala-Schultz, P. J. J. S. Hogan, and K. L. Smith. 2005. Short communication: Association between milk yield at dry-off and probability of intramammary infections at calving. J. Dairy Sci. 88:577-579

Rastani, R. R., R. R. Grummer, S. J. Bertics, A. Gümen, M. C. Wiltbank, D. G. Mashek, and M. C. Schwab. 2005. Reducing dry period length to simplify feeding transition cows: Milk production, energy balance, and metabolic profiles. J. Dairy Sci. 88:1004-1014.

Sangsritavong, S., D. K. Combs, R. Sartori, L. E. Armentano, and M. C. Wiltbank. 2002. High feed intake increases liver blood flow and metabolism of progesterone and estradiol- $17 \beta$ in dairy cattle. J. Dairy Sci. 85:2831-2842.

Santschi, D. E., D. Lefebvre, C. L. Girard, and D. Pellerin. 2009. Short dry period: A new reality? Results from a long term field study. J. Dairy Sci. 92(E-Suppl. 1):332.

Sørensen, J. T., and C. Enevoldsen. 1991. Effect of dry period length on milk production in subsequent lactation. J. Dairy Sci. $74: 1277-1283$

Sorensen, M. T., J. V. Nørgaard, P. K. Theil, M. Vestergaard, and K. Sejrsen. 2006. Cell turnover and activity in mammary tissue during lactation and the dry period in dairy cows. J. Dairy Sci. 89:4632-4639.

Stelwagen, K., I. Politis, J. H. White, B. Zavizion, C. G. Prosser, S. R. Davis, and V. C. Farr. 1994. Effect of milking frequency and somatotropin on the activity of plasminogen activator, plasminogen, and plasmin in bovine milk. J. Dairy Sci. 77:3577-3583.

Ster, C., M. C. Loiselle, and P. Lacasse. 2010. Effect of serum composition on the functionality of bovine peripheral blood mononuclear cells. Page 142 in Proc. Conf. of Res. Work. Anim. Dis.

Tao, S., J. W. Bubolz, B. C. do Amaral, M. J. Hayen, S. E. Johnson, and G. E. Dahl. 2010. Effect of heat stress during the dry period on mammary gland development of dairy cattle. J. Dairy Sci 93(E-Suppl. 1):483.

Tremblay, G., P. Bernier-Dodier, L. Delbecchi, G. F. Wagner, B. G. Talbot, and P. Lacasse. 2009. Local control of mammary involution: Is stanniocalcin-1 involved? J. Dairy Sci. 92:1998-2006.

Trott, J. F., B. K. Vonderhaar, and R. C. Hovey. 2008. Historical perspectives of prolactin and growth hormone as mammogens, lactogens and galactagogues-Agog for the future! J. Mammary Gland Biol. Neoplasia 13:3-11.

Tyrrell, H. F., and J. T. Reid. 1965. Prediction of the energy value of cow's milk. J. Dairy Sci. 48:1215-1223.

Velasco, J. M., E. D. Reid, K. K. Fried, T. F. Gressley, R. L. Wallace, and G. E. Dahl. 2008. Short-day photoperiod increases milk yield in cows with a reduced dry period length. J. Dairy Sci. 91:3467-3473

Watters, R. D., J. N. Guenther, A. E. Brickner, R. R. Rastani, P. M. Crump, P. W. Clark, and R. R. Grummer. 2008. Effects of dry period length on milk production and health of dairy cattle. J. Dairy Sci. 91:2595-2603. 